\title{
MUḤAMMAD SAYYID ṬANṬĀWĪ ON IJTIHĀD: CONCEPT AND TYPOLOGY
}

\author{
Muhammad Lathoif Ghozali \\ Universitas Islam Negeri Sunan Ampel Surabaya, Indonesia \\ E-mail: lathoif@uinsby.ac.id
}

\begin{abstract}
This study aimed at exploring the concept and the typology of $\ddot{j t i h} \bar{a} d$ according to Muhammad Sayyid Tantāwī. The concept was descriptively expressed while analyzing it using content analysis techniques with a comparative approach. Meanwhile, in scrutinizing the biography and ideas of Tantāwō, this study utilizes inductive methods and a socio-historical approach to look at his social and political circumstances and the interaction of a mujtabid with his socio-cultural or sociopolitical environments. The results of the study showed that ijtib $\bar{a} d$ according to Tantāwi $\overline{1}$, is an outpouring of the maximum ability of a mujtabid to arrive at the shari'ah law by means of istinbät of the sharī'ah propositions. The area of jitibād according to Țantāwi is on the zanniyat al-thubüt texts such as the Hadith which is a lot of discussion of the Hadith experts about its sanad, validity, weakness and so forth, or zanniyat al-dilalah, such as the Hadith or the Qur'ān which includes more than one meaning based on the meaning of lughawi or fairness of shari'ah. In addition, the Tantāaw's typology of ijtihäd covers the moderate and middle ground group that pay much attention to maqasid shari'ah, naș, and human interests as long as it does not conflict with nass.
\end{abstract}

Keywords: Tanțāwī; ijtihād; sharī'ah; moderate; Religious Utilitarianism.

\section{Introduction}

In the fourth century of hijrah, the problem of "closing the door of ijtibäd" arose. According to al-Zuhayli, the phenomenon was inseparable from the fact that the Islamic State was divided into several small states and kingdoms, weakening Muslim society 
and breaking their political ties. As a result, the Muslim community experienced the loss of freedom of thought, obstruction of ijtihad activities, and other scientific activities. The ulama were trapped in the bondage of religious fanaticism, loss of selfconfidence, and the development of disagreements. They are fixated on textual figh and ikhtisas. ${ }^{1}$

These problems are the reason why ijtihäd is fard (obligatory) in Islam. Ijtibäd is the spirit of sharíah, or in other words that the development of shari'ah in life depends on ijtihäd. That "closing the door" was also contradicted by al-Suyūtī. He said that ijtihäd is fard at any time, and this world must not be empty of mujtabids, because in every period in society, there are new problems that must be completed and solved by a mujtabid. ${ }^{2}$ Among those who reached the mujtabid level was Muhammad Sayyid Ṭanțāwī.

Tantāiwi is the Grand Mufti of Egypt who was appointed on October 28, 1986. He held this position for nearly ten years, until he was appointed for Grand Imam of the Al-Azhar Mosque and the Grand Shaykh of Al-Azhar University by the President of Egypt, Husni Mubarak, on March 27, 1996 until his death on March 10, 2010. During his life, Tanțāwī was known by some scholars as moderate thinker, and his opinions were often at odds with hard-liner Muslims. Ebrahim Moosa, a Professor at University of Notre Dame, mentioned that Tantāōi is a scholar who possessed a very pluralist and pro-western mindset. ${ }^{3}$

The consistency of Tantāwi in terms of opening the door of ijtihād can be seen from his fatwās. In 1989, Tantāâi said that a certain interest rate based on government investment is not categorized as prohibited usury. ${ }^{4}$ His fatwa caused a storm of controversy with the opposition of all traditional scholars. For instance, Tanțāwi mentioned that the interest on bank deposits is perfectly Islamic. Ṭantāwi suggests that the law should be changed

\footnotetext{
${ }^{1}$ Wahbah al-Zuhaylī, Ușūl al-Fiqh al-Islàmì (Beirut: Dār al-Fikr al-Mu'āṣir, 2001), 1113.

2 Al-Suyūṭī, al-Radd 'alā Man Akblada ilā al-'Ard wa Jabila anna al-Ijtihāed fì Kull 'Asr Fard (Aljazair: Maṭba'at al-Jazā’ir, 1325 H), 3-13.

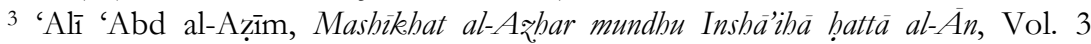
(Cairo: Majma‘ al-Buhūth al-Islāmīyah, n.d.), 925.

4 Muhammad Sayyid Tanțāwī, Mu'ämalāt al-Bunūk wa Aḅkeāmuhā al-Sharì̛yah (Cairo: Hay’at al-Mișrīyah li al-Kitāb, 1998), 106.
} 
to change the legal terminology used for the benefit of banks and bank accounts to explain their freedom from the stigma of usury. This fatwa contradicts the Al-Azhar Islamic Study Institute (Majma“ al-Buhūth al-Islāmìyah) in Egypt.

This study tries to examine the principal thoughts of Tantāwi about ijtihäd, including the method of ijtihäd and legal edicts. The concept of ijtihād seems to be one of the neglected areas of study, especially when compared to other themes in Țanțāwì's thoughts, such as the concept of infidelity (käarir), ${ }^{5}$ ideal family, ${ }^{6}$ istinbät aḅkam, ${ }^{7}$ and his methodology of Qur'ānic interpretation (tafsir). ${ }^{8}$ One may find the study about Tantawi's ijtihad. Still, the idea of ijtihād does not become the main body of study, but only as a supporter of the main themes in the study of other Tantāwi thought.' The study is then to explore the concept of ijtihād of Tantāwī, and to identify its typology, as they are significant in the context of the overall Islamic legal opinion of the Grand Mufti.

This research problem can be formulated as follows: What is the concept of ijtibād of Tanțāwì? What is the typology of legal and ijtihād thinking of Tantāwi ? This study only uses the method of library research. There are two sources used in data mining, namely primary and secondary sources. Primary sources, directly coming

5 Ilham Mustofal Ahyar, "Konsep Kafir Muhammad Sayyid Tantawi: Studi Analisis Kitab Al-Tafsir Al-Wasit li Al-Qur'an Al-Karim dengan Perspektif Hermeneutika Jorge J.E. Gracia" (M.A. Thesis--UIN Sunan Kalijaga Yogyakarta, 2016).

${ }^{6}$ Hawin Uswatun Najah, “Konsep keluarga sakinah dalam al-qur'an kajian tafsir tematik menurut penafsiran Muhammad Sayyid Tantawi dalam karyanya AlTafsir Al-Wasit Li Al-Qur'an Al-Karim" (M.A. Thesis--UIN Sunan Ampel Surabaya, 2016).

7 Muhammad Fadhlan Is, “Analisis Intinbāt Aḥkām Fatwa Muḥammad Sayyid Ṭantāwī yang Kontroversial” (M.A. Thesis--IAIN Sumatera Utara Medan, 2013).

8 Fithrotin, "Metodologi Tafsir Al Wasit (Sebuah Karya Besar Syaikh Muh. Sayyid Tantawi)," AL FURQAN: Jurnal Ilmu al-Qur'an dan Tafsir, Vol. 1, No. 1 (2018), 41-55.

9 To mention one well-representative study, in this respect, is M. Alipour, "Islamic Shari'a Law, Neotraditionalist Muslim Scholars and Transgender Sexreassignment Surgery: A Case Study of Ayatollah Khomeini's and Sheikh alTantawi's Fatwas," International Journal of Transgenderism, Vol. 18, No. 1 (2017), 91-103. 
from the first hand, are namely the works of TTanțāwī; al-Ijtihäd fi alAḅkām al-Shar'ìyah, Mu'ämalat al-Bunūk wa Aḅkämubā al-Shar'ìyah, Adab al-Hịwär fi al-Isläm, al-Wasì fi Tafsìr al-Qur'än, and Figh alMuyassar, while the secondary sources are: Fatwas of the Indonesian Ulema Council by M. Atho Mudzhar, al-Fiqh 'alā al-Madhähib alArba'ah by 'Abd al-Raḥmān al-Jazīrī, al-Fiqh al-Islāmì wa Adillatuh by Wahbah al-Zuhaylī, I'lam al-Muwāìin by Ibn al-Qayyim alJawzīyah, Bidāyat al-Mujtahid by Ibn Rushd, al-Muwāfaqāt fi Usūl alFiqh by al-Shātịī, al-Ashbāh wa al-Nažäir by al-Suyūṭi, and other jurisprudence literatures, the principles of fiqh science, the history of Islamic law, and the sociology of law in general.

As Tantāwī lived during the reign of Gamal Abd al-Nasir, Anwar Saddat, and Husni Mubarak, this study therefore uses historical approach to analyze Ṭanțāwì's biography and contextualize his thought, ${ }^{10}$ usül al-fiqh approach to give a basis for content analysis used in this study, and comparative approach to compare the ijtibād of Tantāwī with that of other experts before him, whether his thoughts are influenced by other figures or purely from his own.

\section{Biography of Ṭanțāwī}

Muhammad Sayyid 'Ațiyyah Muhammad Sayyid Ṭanțāwī was born in the village of Sulaym, Markaz Thama Suhaj Province on 14 Jumādā al-Ūlā, 1347 H., coinciding with October 28, 1928. His father vowed that his son would become a lover of knowledge, until Tanțāwi grew to be a person who loves knowledge, memorizes the scriptures of the Qur'ān, when he was thirteen years old or just graduated from the madrasah ibtida' 'yyah (primary school) level. ${ }^{11}$ Tanțāwi learned the basics of religious knowledge in his village. After memorizing the Qur'ān, he continued to enter a ma'bad diniyah in Alexandria in 1944. Then after graduating from madrasah thanawiyah (secondary school level), he continued his education to the Uṣūl al-Dīn Faculty at al-Azhar University and

\footnotetext{
10 This is because every product of Islamic legal thinking is basically the result of the interaction of a mujtahid with the socio-cultural or socio-political environment that surrounds it. Peter Mahmud Marzuki, Penelitian Hukum (Jakarta: Kencana, 2009), 126.

11 Al-'Azīm, Mashikhat al-Az̧har, 929.
} 
graduated in 1958. In 1959, Tantāāi completed his "specialist" education at al-Azhar, on the study program of Tafsìr and Hadìth. Then in September 1966, he received his doctorate in the field of Hadìth, and was honored mumtār, after defending his dissertation entitled "Banū Isrā̄îl fī al-Qur'ān wa al-Sunnah."

Ṭantāwi is widely known as a zubd, calm, and cool looking eyes. The words of him can pierce into the souls of those who want to understand it. Tantāâ is is a person who is very strong and even too absorbed in reading, so that he is told to tell one of his servants to wait and remind him when prayer time has arrived. This is because if he read at the beginning of the morning, it will only be finished reading if it has entered the time of nobility.

After his study completed, Ṭantāini became Khätib and lecturer at the Ministry of Wakaf in Egypt in 1960, and eight years later, precisely in 1968, he became a lecturer of Tafsìr and Hadith at the Ușul al-Dīn Faculty of al-Azhar University. In 1972, he enrolled as an Assistant Professor position at the faculty, al-Siyut branch. This position then lead him to be a lecturer at the Islamic University of Libya in 1972-1976. His capabilities and intelligence brought him into higher position as a Dean at the Ușūl al-Dīn Faculty Al-Azhar University, al-Siyut branch. In addition, he was also a Head of the Tafsir study program of the Postgraduate Studies of Islamic University, Medina, Saudi Arabia, 1980-1984, and Dean of the Faculty of Dirāsāt al-Islāmīyah wa al-'Arabìyah, al-Azhar University, in 1985. In 1986-1996, Tantậai became the Mufti of Egypt.

On 8 Dhū al-Qa'dah 1416 H., coinciding with March 27, 1996, Tanțāwi was appointed as Shaykh al-Azhar. ${ }^{12}$ Tanțāwī completed the program of Shaykh 'Abd al-Halīm Mahmūd (the $40^{\text {th }}$ Shaykh of al-Azhar), which is to restore all al-Azhar assets that have been seized by the Egyptian government for hundreds of years since the leadership of Ismā̄ill Pasha. When Aceh, Indonesia, was rocked by the Tsunami in 2004, Ṭantāwi took the policy of providing scholarships to all al-Azhar students from Indonesia, without exception. This is a form of concern of the al-Azhar's Shaykh to his students. Tantāiwi is an active reader and writer, some of his works are: Banū Isrä̀il fì al-Qur'ān wa al-Sunnah (1969), Tafsìr al-

12 Ibid., 931. 
Wasit li al-Qur'ān al-Karim (1972), al-Qișsah fi al-Qur'ān, al-Ijtibäd fi alAḅkām al-Shar'ìyah, al-Fiqh al-Muyassar, al-Mar'ah fi al-Islām, Mu'ámalat al-Bunük wa Aḅkämubā al-Sharìyah (1991).

\section{Ijtihād According to Ṭantāwī}

Ijtihäd originally derived from the Arabic word jabada-yajhadujubdan wa jahdan. Al-jubd means power, ability, and strength while al-jahd means al-mashaqqah or difficulty. Etymologically, ijtihäd means badbl al-wus" wa al-majbüd or mobilization of power and ability. ${ }^{13}$ The change from the word jahada to ijtahada occurs by adding two letters (mazid harfayn): alif at the beginning and $t a$ ' between the letters jim and dal, so that it becomes ijtahada-yajtabiduijtibädan, meaning a real action by exerting all abilities. ${ }^{14}$ Thus, in this respect, the word ijtihäd means devoting abilities and spending opportunities in realizing an affair from an existing problem (badhl al-majbüd wa al-istifrägh al-wus' fì tahqiq amr min al-umür) or outlining the ability of a fiqh expert to produce shar ’⿳亠̣ zannī legal conclusions

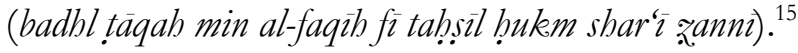

According to Ṭantāini, ijtihäd is:

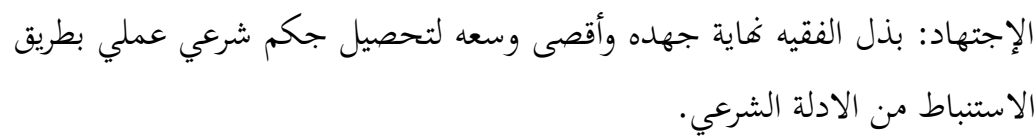

"An outpouring of the maximum ability of a fiqh expert (mujtabid) to arrive at the shari'ah law of 'amali by way of istinbät from the shari' ${ }^{\circ}$ ah arguments." ${ }^{\prime 16}$

As a comparison, al-Āmidī (d. $631 \mathrm{H})$ defines ijtihād as:

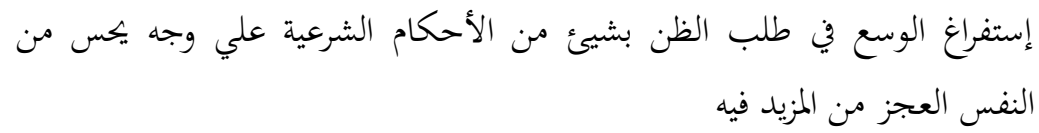

"Depleting the ability to search strongly for a legal problem until it feels there is no additional capability in its search." 17

\footnotetext{
13 Ibn Manẓūr, Lisān al-'Arab, Vol. 3 (Mesir: Dār al-Miṣrīyah li al-Ta’līf wa alTarjamah, n.d.), 107-108.

14 Luwīs Ma'lūf, al-Munjid fì al-Lughah wa al-A 'làm (Beirūt: Maktabat Dār alMashriq, n.d.), 106.

15 Al-Zuhaylī, Usūul al-Figh, 1037.

16 Muḥammad Sayyid Ṭanțāwī, al-Ijtihād fì al-Aḥkām al-Sharî̀yah (Cairo: al-Azhar al-Sharīf, 2007), 9.
} 
Al-Shawkānī (d. $1250 \mathrm{H}$ ) gives the definition of ijtihād by means of:

$$
\text { بذل الوسع في نيل حكم شرعي عملي بطريق الاستباط }
$$

"Exerting the ability to obtain practical sharí'ah law 'amali through istinbät."."

Ijtihäd relates to two cases, ijtihäd in the matter of taqlidiyah and ijtihäd in matters for which there is no basis yet. ${ }^{19}$ According to alShātibī (d. 790 H), ijtihäd are of two kinds, ijtihäd in dark al-aḅkām al-shariyyah (find, know the law of sharī'ah) and ijtibäd in tatbiq alableam al-sharizyah (applying shari'ah law). The first form of ijtibäd is particular in nature that should only be done by those who meet the qualified qualifications to do so, while the second one is general in nature that is permissible for all Muslims. ${ }^{20}$

Tantāwī discusses the object or scope of ijtihäd in his book alIjtibād. According to him, the area of ijtihäd is in zanniyyät al-thubüt text like the Hadith in the terms of its sanad, validity, weakness, and so forth; or zanniyyät al-dilälah, such as the Hadìth or the Qur'àn that includes more than one meaning, either luqhawi or adillah shariyah. Like the verses of al-Mă'idah about ablution, every Muslim recognizes that the verses are qat'i al-thubüt. The difference among scholars about the verses is only in understanding the meaning of them. Regarding the words famsahū bi ru'üsikum, scholars have agreed that rubbing the head is including the pillars of ablution based on the argument of mantīq from the above verse, but they differ about the level of the head that must be rubbed. ${ }^{21}$

Al-Ghazāli (d. $505 \mathrm{H})$ argued that the ijtihäd area is any sharíah law which has no proof of qat $i$. Therefore, it does not enter the area of all laws agreed upon by the people as having a clear

17 Al-Āmidī, Al-Ị̣keàm fì Ușùl al-Aḥkām (Beirut: Dār al-Kutub al-Islāmīyah, n.d.), 218.

18 Al-Shawkānī, Irshād al-Fuhūl fì Tlm al-Usùl (Beirut: Dār al-Kutub al-Islāmīyah, n.d.), 250.

19 'Abd al-Halīm, Fatāwà (Cairo: Maktabat al-Tawfīqīyah, n.d.), 362.

20 Abū Ishạāq al-Shạtibī, al-Munvāfaqāt fì Ușül al-Sharíah, Vol. 4 (Beirut: Dār alKutub al-Islāmīyah, n.d.), 64; Muḥammad Abū Zahrah, Ușül al-Fiqh (Beirut: Dār al-Fikr, n.d.), 379 .

21 Ṭantāini, al-Ijtihād, 11. 
understanding of their meaning, such as the obligation to pray five times a day, pay zakat, and so forth. ${ }^{22}$

According to al-Zuhaylī, there are laws that are ijtihäd areas and laws that are not ijtibäd areas. ${ }^{23}$ The laws which are not the area of ijtibàd are laws that are generally accepted and known, and determined based on the proofs of qat $\bar{\imath}$ al-thubüt-qat $\bar{c}$ al-dalälah. Such laws are like the issue of the obligatory five-time prayers, fasting in Ramadan, zakat, haji, reading shabadatayn, then the prohibition of adultery, stealing, killing, drinking khamr, and the sanctions imposed by the Qur'ān or Sunnah. ${ }^{24}$

While the laws which are the area of ijtibad, according to alZuhayli, include: the law that already has a text, but its doubt and the designation of its meaning is unclear zanni al-thubüt wa zanni aldalalab; the law that already has the texts but the outwardity is doubtful zanni al-thubüt, the law that already has a text, but the designation of its zanni al-dalälah meaning is not clear; and a law that does not have a passage and has never been existed before. ${ }^{25}$

In terms of the presence or absence of the Qur'ān or Sunnah scriptures that govern, the legal events that occur can be grouped into three types. First, the legal event that has nass shari qat i alwurüd wa qat'i al-dalalah (authentic-definite origin from the Prophet and clearly his appointment to the meaning that referred to). Second, legal events that have nass sharì zanni al-wurüd wa al-dalälah aw iḥdāhumā (assumed or lack of clear designation). Third, legal events that do not have nass shar'i at all.

In the first category of legal events, since it has been regulated by nasss shar'i qat'i al-wurüd wa qat'i al-dalälah, the implementation of ijtihäd fi dark a plemiha is no longer needed. Meanwhile, ijtihäd fi tatbiq abkämiba still remains necessary. Put the sanctions for thieves, for instance, in this respect. To find out the sanctions for a thief do not need ijtibäd because there is already a qat $i$, as recited by al-Mā'idah [5]: 38 which has determined the level of legal sanctions clearly in the form of hand deductions; "Men who steal

\footnotetext{
22 Abū Ḥāmid al-Ghazālī, al-Mustasfā fì Tlm al-Ușūl, Vol. 2 (Beirut: Dār al-Kutub al-'Tlmìyah, 1993), 315.

23 Al-Zuhaylī, Ușül al-Fiqh, 1052-1054.

24 Ibid., 1052.

25 Ibid., 1053-1054.
} 
and women who steal, cut off both hands (in retaliation) for what they do and as torture from Allah. And Allah is Mighty, Most Wise."

Legal events that fall into the second category that have nass. shar zanni, the ijtihäd fi dark ablkamiha may be implemented. With respect to naș zanni al-wurüd, like Hadīth aḅäd, jitibäd is oriented to prove whether the Hadith originated from the Prophet or to establish his ratification, while in naș zanni al-dalälah, ijtihàd is implemented to find the exact meaning of the nass instructions. Perhaps, by interpreting the nass, or capturing it, or choosing the right meaning of the mushtarak pronunciation, or completing ta'arud (contradictions between nasss) with another nass, or compromising, or establishing its kehās or 'àm, mutlaq or muqayyad, or determine whether an order shows mandatory or not, its prohibition indicates unclear or not, and so forth.

\section{Mujtahid Qualifications According to Ṭanțāwī}

In his book, al-Ijtibād, Ṭantāwi explained that a mujtabid must have some qualifications. ${ }^{26}$ First, knowledge of Arabic. The main requirement for becoming a mujtabid is knowing Arabic with all its aspects, by which he can understand the Qur'ān which also uses Arabic. Moreover, the Qur'ān and Sunnah as a source of Islamic legal rights present themselves in the form of a very high-Arabic literature style. A mujtabid cannot possibly understand and explore the laws contained in the Qur'ān and Sunnah without being based on Arabic knowledge. ${ }^{27}$ The ability of Arabic with all its aspects which includes such sciences as of Naḥw, Șarf, Bayān, Ma'ānī, Badī', and others helps a mujtabid to explore the intentions of Allah's will in the Qur'ān precisely and far from mistakes, and to produce strong legal conclusions. Regarding the quality of Arabic skills required as a condition for mujtahids, there are several different opinions.

Al-Ghazâlī determines certain abilities in language, which allow a mujtabid to distinguish the pronunciation, including sarih, haqiqah,

\footnotetext{
26 Ṭanțāwī, al-Ijtihād, 13.

27 'Abd al-Karīm Zaydān, al-Wajī̌ fì Usül al-Figh, Vol. 6 (Beirut: Mu'assasat alRisālah, 1994), 402.
} 
majār, sāhir, mujmal, separating between 'àm and khäs, muḅkam and mutashäbibät, mutlaq and muqayyad, nass and mafhüm. ${ }^{28}$

Al-Shătibī does not demand certain limits but states that the quality of ijtihäd results achieved by a mujtahid is in line with his language abilities. If the language skills are still in the basic level, then it is still basic in understanding the shari' ah. Likewise, if the language ability reaches intermediate level, then the understanding of the shari'ah is still intermediate as well. If the language ability reaches the advanced stage, then the understanding of the shari'ah has also reached the advanced stage by which a mujtabid reaches the power of bujjah. ${ }^{29}$

Thus, the mastery of Arabic with all its aspects is crucial for a mujtabid to understand the meaning of the content and the desired direction of the Qur'ànic scriptures and the Sunnah. However, language is not the only condition, since other factors, such as the social, psychological, and historical conditions of nuzūl al-ayyat or wurüd al-Sunnah also greatly help correct understanding.

Second, knowledge of the Qur'àn. The Qur'ān is the main source of law, so that all ulama agree that knowledge of the Qur'ān is a sufficient requirement for a mujtabid. It is not possible for a person to explore, formulate, and understand the law without having knowledge of the Qur'ān and all forms of its character. ${ }^{30}$ The fact that the Qur'ān introduces itself with various characteristics is a reason why the Qur'ān becomes a book whose authenticity is guaranteed by Allah and is used as a fundamental reference for solving legal problems. ${ }^{31}$ In addition, in its designation of a meaning, nass of the Qur'ān displays two characteristics, namely qat 'i al-dalälah and zanni al-dalälab. ${ }^{32}$

The scope of the discussion of the Qur'ān and 'ulum al-Qur'ān is very broad, so that the scholars do not require to memorize the entire verses of it. They limit the understanding of the Qur'ān only to the law verses, without having to memorize but know the context when needed to discuss a law. Al-Ghazālī and al-Shawkānī

\footnotetext{
28 Al-Ghazālī, al-Mustasfā, 315.

29 Al-Shātibīi, al-Muwāâāàt, Vol. 2.

30 Zaydān, al-Waǰř, 402.

${ }^{31}$ M. Quraysh Shihab, Membumikan al-Qur'an (Bandung: Mizan, 1994), 21.

32 Mukhtar Yahya and Fatchurrahman, Dasar-dasar Pembinaan Hukum Islam (Bandung: Al Ma'arif, 1997), 37-38.
} 
gives a limit to the memorization of the Qur'ān only in the amount of 500 verses. ${ }^{33}$

A mujtahid must have sufficient understanding of the language of the Qur'ān so as to be able to separate and understand between verses mublkamät and mutashäbihät, mantūq and mafhüm, mutlaq and muqayyad, haqüqah and majār, sarị̆ and kināyāt, amr wujūb and amr ghayr wujūb, nahi tabrim and nabi ghayr tabrim, etc. ${ }^{34}$

Third, knowing the traditions of the Prophet. A mujtahid may give a fatwa $\bar{a}$ or ijtihād if it meets the qualifications of understanding the Hadith of the Prophet Muhammad, as well as the sciences related to it so that the fatwa or ijtihäd does not actually conflict with the Hadith of the Prophet. The knowledge of a mujtabid about the Hadith of the Prophet make him possible to know and distinguish between Hadith mutawatir and Hadith abäd, between Hadith sahīh, hasan, and da iff. He is also required to be able to know Hadith maqbül (accepted as a legal basis) and Hadith mardūd (rejected cannot be used as a legal basis). ${ }^{35}$

Because of the broad scope of the Hadith and the related sciences ("ulum al-Hadith), ${ }^{36}$ which is not possible for a mujtahid to reach the whole of them, the ulama of usull therefore limits the requirements of mujtabid knowledge about the Hadith, preferably in the related traditions with the laws of taklifiyyat which enables him to find the law in the hadith. They do not require having to memorize the hadith by rote, but rather knowing where it is possible to refer to it when needed. ${ }^{37}$

Forth, knowing of usül al-fiqh and maqäsid al-shari'ah. A mujtahid currently must have adequate knowledge about the science of usiul al-figh and the maqäsid al-shari' ah, because this knowledge learns what is needed for ijtihad. With this knowledge, a mujtahid will be able to return the branch law to the original law in an easy way. Conversely, if he does not master the science of ussul al-fiqh, it will have difficulty in returning the problem and even errors will occur.

\footnotetext{
33 Al-Ghazāì̄, al-Mustasfā, 101; al-Shawkānī, Irshād al-Fubūl, 220.

34 Al-Ghazālī, al-Mustasfā, 101-102.

35 Muhammad Ajjāj al-Khatịib, Ușūl al-Hadìth Uhümuhā wa Muștalāhuhā (Beirut: Dār al-Fikr, 1980), 287-280 and 303-353.

${ }^{36}$ Ibid.,11.

37 Al-Zuhaylī, Ușül al-Figh, 1156.
} 
Included in the science of usūl al-fiqh is knowing näsikh wa almansükh. According to al-Zuhaylī, this knowledge is also a requirement for a mujtabid so that in doing ijtihäd he does not violate the rules which apply, both the rules of näsikh mansükh and the agreed rules of Islamic law.

Fifth, the intelligence and reasoning ability to perform ijtihäd. Ṭantāinì agree with 'Abd al-Karìm Zaydan about the importance of intelligence and the ability of reason as a basic condition even though among the ulama of usūl they are not explained clearly. A mujtabid must have the ability of reasoning and understanding, high comprehension, power of accuracy as well as the qualified ability to analyze. Without this requirement, a person will not be able to do the ijtihäd even if other requirements have been fulfilled. It seems that this requirement leads to mastery of Mantiq/Logic science, which in the view of other ulama it has included in the mastery of usül al-figh and ulüm al-Qur'än as well as ulüm al-Hadith. Meanwhile, the intelligence leads a mujtabid to orderliness of thinking starting from capturing information to drawing conclusions.

Regarding the words "opening of the door of ijtibad" and that "the ijtihäd door is closed," Tantāwi agrees with the usūl scholars before him, such as al-Suyūṭ̂ and Ibn Taymìyah who stated that ijtihād both in the form of istinbät al-ahkām and tatbiq al-aḅkàm were never closed. ${ }^{38}$ The Tantāwi's opinion is in line with Yūsuf alQaraḍāwi. Dealing with the opening of the door of ijtibād in modern times, al-Qaraḍ̄āi identified different opinions from three flow groups. ${ }^{39}$

First, the flow that narrows and complicates ijtihad. Sectarianism is a group that believes in the obligation to follow certain madhhab, and may not leave the madhhab, and is obliged on new issues, to follow the opinions that exist within its own environment, by endorsing the opinions of muta'akhkhirin ulama directing the books of that madhhab. Often in the field of mu'āmalah, they forbid new forms of transactions with

\footnotetext{
38 Al-Suyūtī, al-Radd, 3-13.

39 Yusuf al-Qardlawy, Ijtihad dalam Masyarakat Islam (Beberapa Pandangan Analitis tentang Ijtihad Kontemporer), translated by Achmad Syathori (Jakarta: Bulan Bintang, 1987), 255-260.
} 
contradictory reasons or are not in the reference to the madhhab. The neo-zäbiryah group is a literal and textual group, understanding the nass literally without accepting any other understanding. They pursue the Hadith by not practicing figh and not wanting to know the differences in jurisprudence and how to observe the law. Currency is only made of gold and silver that existed at the time of the Prophet, while that of made from paper are not considered shar $i$, so that it do not apply to usury laws and not to obligatory zakat.

Second, excessive extreme flow in expanding the field of ijtihäd even in nass mubkeamat and fixed laws. This flow was followed by two groups namely the al-Ṭuffiyah and the al-Tabrīr. Al-Ṭufiyah is a group that is concerned with maslahah from nass. This group is attributed to Najm al-Dīn al-Ṭúfí who prioritizes mașlabah from the nașs, if both are in conflict. Al-Tabrìr is a group that gives legitimacy to any problems that occur in accordance with what is desired by the public or by the ruling Government. This group acts as a validator and provides arguments for problems that occur by looking for interpretations of arguments from shari'ah arguments that support so that the problem can be accepted.

Third, the moderate madhhab as a group that takes a middle way that unites the attitude of following nass and pays attention to his maqassid al-shari ${ }^{-6}$, and to human interests with the provisions that these interests are not contrary to the naș. This group consists of people who are equipped with enough knowledge, have the character of the guard against the influence of volition, and be straight that are neither extreme nor apathetic. This flow is a group that is needed today as a reflection of Islam that takes the middle ground of other religions desired by Allah in al-Baqarah [2]: 143 which recites:

"And so (also) We have made you (Muslims), a just and chosen people so that you can be a witness of (human) deeds and that the Apostle (Muhammad) is a witness to your (deeds). And We did not set the Qibla that became your Qibla (now) but so that we knew (so that it was real) who followed the Apostle and who defected. And indeed (the transfer of Qibla) feels very heavy, except for those who have been instructed by Allah, and Allah will not waste your faith. Truly Allah is Most Gracious, Most Merciful to humans." 
Al-Qaraḍāwī includes into groups who call on j̈tihäd without fear and worry, so that ijtihäd continues to walk straight and does not turn backwards, and do not turn to the right or left. To that end al-Qaraḍāwi gives contemporary ijtibād rules with several characters as follows: (a) There is no ijtibäd without devoting all of his abilities; (b) There is no ijtihäd in qat ${ }^{t} \bar{\imath}$ legal matters (definitely and clearly); (c) Must not regard the laws that are qat ${ }^{6} ;$; (d) Linking jurisprudence to Hadith; (e) Take care not to fall under the pressure of the reality of the modern world; (f) Welcomes a useful new discovery; $(\mathrm{g})$ Should not be unaware of the conditions and situations of the times and their needs; (h) Switch to ijtibäd jama $\bar{a}$ i (collective); and (i) it is Grace that there is a possibility of correction by the next generation of ulama, because of possible errors or other negligence. ${ }^{40}$

The urgency of contemporary ijtihäd from ulama who have fulfilled mujtabid qualifications and with sincerity is very much felt, and is a hope to answer all legal problems that will continue to emerge, due to socio-cultural changes in society and advances in science and technology.

\section{Sources of Ijtihād According to Ṭantāwī}

The author found the term masadir al-ijtibäd (sources of ijtibad) in Mawsü'ah al-Fiqhiyah al-Kuwaytīyah, Vol. 1, page 41 and Usūl al'Ammāh al-Jämi'ah li al-Fatâwā, Vol. 1, page 20. What is meant by masadir al-ijtihäd here is the guide/guidance of a mujtahid in seeking legal answers about a problem. The word "source" in Indonesian means 'the place of origin,' and from there the term source of Islamic law can be interpreted as the origin of the place of taking Islamic law. ${ }^{41}$ In Arabic, the word "source" is, among others, called masdar from the plural masädir. So in usūl al-fiqh, the source of Islamic law is termed al-abkeam al-shariyah. But sometimes it is used with the term usül al-aḅam which means legal basics. It is also used dalil al-hukm with the plural adillat al-ạ̣kām which means something from which there is a clue to the sharīah law.

\footnotetext{
40 Ibid., 261-273.

41 Departemen Pendidikan dan Kebudayaan, Kamus Besar Bahasa Indonesia (Jakarta: Balai Pustaka, 1988), 867.
} 
In the Islamic law literatures in Indonesia, the words masadir alaḅkàm, ușül al-aḅkām, and adillat al-aḅkām are all interpreted with the sources of Islamic law. The word "masädir al-aḅkäm" in usül al-fiqh was only used around the end of the $14^{\text {th }}$ century of hijrah, or the mid of the $20^{\text {th }}$ century, namely with the publication of several books of usül al-figh which uses masädir to cite sources of legal returns. Among the books is the work of Zakariyyā al-Ṣabrī entitled Masādir al-Aḥkām al-Islämìyah.

The ulama analyze and say that the word "masàdir," "usūll," and "dalip" are included in the meaning of istinbät al-ahkam in general. Therefore to distinguish the whole is to mention dalil naqli or masădir al-naqlīyah for the original source of the Qur'ān and Sunnah, as for the method istinbät called dalìl 'aqli or masädir al'aqliyah. ${ }^{42}$

From a technical point of view of its use in Islamic law, the word "dalī" can also be used in general, both the Qur'ān and Sunnah as well as for dalil other than both, such as ijmá' and qiyass, since they all lead to the discovery of God's law. ${ }^{43}$ Therefore, for the Qur'ān and Sunnah, in addition to being referred to as the source of Islamic law, it can also be called as the proposition of Islamic law. Referred to as a source, it is because the Qur'ān and Sunnah are sources of all the provisions and norms of Islamic law. Meanwhile, called as proposition, it is because they lead a mujtabid to find the law for the actions of a believer.

In addition to the Qur'ān and Sunnah, the experts of ușul al-fiqh also stipulate that the source of the law includes $i j m \bar{a}^{-}$and qiyass. The Qur'ān revealed by Allah contains teachings so that Muslims are also guided by the Sunnah, ijma $\bar{a}^{-}$, and qiyass. From this understanding, the majority of ulama of usül al-figh stated that the agreed legal sources were the Qur'ān, Sunnah, ijmä', and qiyass. However, 'Abd al-Wahhāb Khallāf as the contemporary ulama of us ül al-figh states that the true source of law is the Qur'ann and Sunnah, while the ijmáa and qiyas are methods of exposing the law

\footnotetext{
42 Zakariyyā al-Ṣabrī, Mașādir al-Aḅkām al-Islāmīyah (Makkah: Dār al-Ijtihād al'Arabī, 1975), 13.

43 Amir Syarifuddin, Usul Fikih I (Jakarta: Logos Wacana Ilmu, 1997), 43.
} 
of the Qur'ān and the Sunnah. Ijmā' and qiyas are those based or relied on the Qur'ān and the Sunnah. ${ }^{44}$

The author is more inclined to the opinion of Khallaf, because the Qur'ān and Sunnah are the source of all laws. Every legal provision produced by the ulama will never be separated from the Qur'ān and the Sunnah. While ijmā' and qiyās are only an alternative way of taking istinbät al-ḅukm, the Qur'ān and Sunnah will continuously be used as the basis of the correct law.

Then the source of $i j t i b \bar{a}$ for Muslim is sourced from Allah through intermediaries of revelation. The Qur'àn is the main source since it is a revelation coming from Allah as waby al-matluw (the process was received by the Prophet Muhammad through the reading of Jibril). Then the second source is the Sunnah as a ghayr al-matluw revelation (accepted directly by the Prophet Muhammad without Jibril's intermediary). Ijmā becomes the accompanying source of ijtihäd if the $i j m \bar{a}^{-}$is based on the ulama agreement in opening the veil of Allah's law. Likewise, qiyäs becomes a source of accompaniment of a mujtabid who already has ijtihäd requirements in opening the veil of Allah's law.

\section{Typology of TTanțāwī's Islamic Legal Thoughts}

The methodological offerings of modern scholars and those who are different from the classical scholars emerged after Muhammad 'Abduh (d. 1905). Under the influence of Abduh's liberal and rational thought, there came new methodological offers that sought to explore Islamic law from its original sources (te Qur'ān and Sunnah) to adjust to the dynamics of the times. According to Hallaq, the offer of this new methodology is not the same as the classical ulama's methodology which devotes more attention to the literal interpretation of verses of the Qur'ān and the matn of Sunnah. Hallaq divides the group that offers this new methodology to two groups, namely Religious Utilitarianism and Religious Liberalism.

The cornerstone of the theory of Religious Utilitarianism group is the concept of maslahah which was a long-standing controversy from among the classical traditional scholars.

44 'Abd Wahhāb Khallāf, Tlm Usùl al-Fiqh (Cairo: Dār al-Qalam, 1978), 101. 
Maslahah, this group is working on, is in the field of mu'amalah, both mu'amalab mälìyah or mu'ämalab siyasizyah. This is because the revelation texts that explain this are limited and more global in nature.

The Religious Liberalism group emphasizes the deictic relationship between the commandments of the text of revelation and the reality of the modern world. The approach used is to understand revelation both in terms of the text and its context. The relationship between the text of the revelation and modern society is not composed through literal interpretation but through interpretation of the soul and the universal message contained in the text of the revelation. ${ }^{45}$

Țantāwīi, from childhood until the end of his life, struggled and took part in the world of Islamic science, and showed his seriousness or sincerity (mujähadab) in seeking and spreading Islamic knowledge. It is appropriate for him to get the title as mujtahid, it is just that his level of mujtabid is the mujtabid fatwa, because in answering the problems faced in addition to using the ijtihäd methods that already exist, he also often answers the problem by highlighting the opinion of the previous scholars especially al-Shāfíī or Shafi'īyah scholars.

In terms of the dynamics of ijtihäd, Tantāani, is not too, but classified as, moderate. To that end, he takes a middle ground that unites attitudes following nașs, and pays attention to maqāsid alshariah and the human interests that are not contrary to the nass. Ṭantāini belongs to a group that is armed with sufficient knowledge, has the nature of warä', guards against the influence of volition, and straight that is neither extreme nor apathetic. This Tantāwì's model of legal thinking is as a type of thought that is needed today as a reflection of Islam taking the middle way from other religions desired by Allah as it is recited in al-Baqarah [2]: 143.

The ijtihäd model undertaken by Tantāwi is in the form of ijtibād tarjī al-intiqa' $\bar{\imath}$ that attempts to take Islamic law containing fatwās and legal decisions. So that his level of mujtabid is mujtabid

\footnotetext{
45 Wael B. Hallaq, A History of Islamic Legal Theories: An Introduction to Sunni Ușūl al-Fiqh (Cumbridge: Cumbrigde University Press, 1997), 231-253.
} 
fatwa by selecting strong and relevant opinions to the condition of his country. Social changes that occur within a community caused by several factors, including population, habitat, physical, technological, and community structural and cultural. Whereas the process can be driven by the advancement of the education system, the attitude of tolerance towards deviant behavior, an open social stratification system, the level of heterogeneity of the population, and a sense of dissatisfaction with certain living conditions. $^{46}$

Changes in law in a society always have two functions, namely as social engineering and social control. In its function as a legal social engineering, it creates changes in social structure that spur people to want and be able to move. While its function as legal social control has the opposite role, namely maintaining social stability, controlling the direction and controlling the speed of change in society so as not to break out of applicable provisions. In this last function, the law is always often considered to be lagging the change itself. On the one hand the law is considered to curb various activities in society, while on the other hand the dynamics of society always require that the law adjusts to the needs of the times. ${ }^{47}$

\section{Conclusion}

From the previous explanations, this study can conclude that; the concept of ijtihad, according to Tantāwī, is an outpouring of the maximum ability of a faqih (mujtabid) to arrive at the shari'sah law of 'amali by means of istinbät of the shari'ah propositions. The area of ijtihäd according to Tantāiōi is on zanniyyāt al-thubüt texts, such as the Hadith and all aspects relating to it, such as sanad, validity, weakness, and so forth, or zanniyyat al-dilalah, such as the Hadīth or the Qur'ān which includes more than one meaning of luqbawi or fairness of shariyah. The conditions that must be fulfilled by a mujtahid, according to Țanțāwi, are that he has knowledge of Arabic and dalälab; memorizes the Qurān and knows its meaning; knows the traditions of the Prophet and all aspects relating to the

\footnotetext{
46 Soerjono Soekanto, Beberapa Permasalahan dalam Kerangka Pembangunan di Indonesia (Jakarta: Yayasan Penerbit UI, 1975), 40-42.

${ }^{47}$ Ibid.,146-147.
} 
science of traditions; understands sharī'ah and customary maqäsid; masters the science of jurisprudence and its basic; and has a sense of intelligence. The Tantāwì's Islamic legal thoughts is classified Religious Utilitarianism group. In term of the dynamics of ijtibäd, Ṭantāwi also belongs to the moderate sense as well as a group that takes a middle ground that unites attitudes to follow nass, pays attention to maqassid al-sharíah, and human interests provided that these interests do not conflict with naș.

\section{Bibliography}

Ahyar, Ilham Mustofal. "Konsep Kafir Muhammad Sayyid Tantawi: Studi Analisis Kitab Al-Tafsir Al-Wasit li Al-Qur'an Al-Karim dengan Perspektif Hermeneutika Jorge J.E. Gracia." M.A. Thesis--UIN Sunan Kalijaga Yogyakarta, 2016.

Alipour, M. "Islamic Shari'a Law, Neotraditionalist Muslim Scholars and Transgender Sex-reassignment Surgery: A Case Study of Ayatollah Khomeini's and Sheikh al-Tantawi's Fatwas," International Journal of Transgenderism, Vol. 18, No. 1, 2017.

Āmidī (al). Al-Iḥkām fì Ușūl al-Aḥkām. Beirut: Dār al-Kutub alIslāmīyah, n.d.

Azụim (al), 'Alī 'Abd. Mashīkhat al-Az̧har. Cairo: Majma' al-Buhūth al-Islāmìyah, n.d.

Departemen Pendidikan dan Kebudayaan. Kamus Besar Bahasa Indonesia. Jakarta: Balai Pustaka, 1988.

Fithrotin. "Metodologi Tafsir Al Wasit (Sebuah Karya Besar Syaikh Muh. Sayyid Tantawi)," AL FURQAN: Jumal Ilmu alQur'an dan Tafsir, Vol. 1, No. 1, 2018.

Ghazālī (al), Abū Hāāmid. Al-Mustassā fì Tlm al-Ușùl, Vol. 2. Beirut: Dār al-Kutub al-'Tlmīyah, 1993.

Halīm (al), 'Abd. Fatāwāa. Cairo: Maktabat al-Tawfīìiyah, n.d. Hallaq, Wael B. A History of Islamic Legal Theories: An Introduction to Sunni Ușül al-Fiqh. Cumbridge: Cumbrigde University Press, 1997.

Ibn Manzūr. Lisān al-'Arab, Vol. 3 (Mesir: Dār al-Mișrīyah li alTa'lif wa al-Tarjamah, n.d.), 107-108. 
Is, Muhammad Fadhlan. "Analisis Intinbāt Aḥkām Fatwa Muhammad Sayyid Ṭantāāi yang Kontroversial.” M.A. Thesis-IAIN Sumatera Utara Medan, 2013.

Khallāf, 'Abd Wahhāb. 'Ilm Ușül al-Fiqh. Cairo: Dār al-Qalam, 1978.

Khațīb (al), Muḥammad Ajjāj. Ușūl al-Hadìth Ulümubā wa Muștalähuhā. Beirut: Dār al-Fikr, 1980.

Ma'lūf, Luwīs. Al-Munjid fì al-Lughah wa al-A làm. Beirūt: Maktabat Dār al-Mashriq, n.d.

Marzuki, Peter Mahmud. Penelitian Hukum. Jakarta: Kencana, 2009.

Najah, Hawin Uswatun. 'Konsep keluarga sakinah dalam al-qur'an kajian tafsir tematik menurut penafsiran Muhammad Sayyid Tantawi dalam karyanya Al-Tafsir Al-Wasit Li Al-Qur'an AlKarim.” M.A. Thesis--UIN Sunan Ampel Surabaya, 2016.

Qardlawy (al), Yusuf. Ijtihad dalam Masyarakat Islam (Beberapa Pandangan Analitis tentang Ijtibad Kontemporer), translated by Achmad Syathori. Jakarta: Bulan Bintang, 1987.

Șabrī (al), Zakariyyā. Mașādir al-Aḥkeàm al-Islāmìyah. Makkah: Dār alIjtihād al-'Arabī, 1975.

Shātibīi (al), Abū Isḥāq. al-Muwāfaqāt fì Ușūl al-Sharīah, Vol 2 and Vo. 4. Beirut: Dār al-Kutub al-Islāmìyah, n.d.

Shawkānī (al). Irshād al-Fuḅül fì Tlm al-Ușül. Beirut: Dār al-Kutub alIslāmìyah, n.d.

Shihab, M. Quraysh. Membumikan al-Qur'an. Bandung: Mizan, 1994. Soekanto, Soerjono. Beberapa Permasalahan dalam Kerangka Pembangunan di Indonesia. Jakarta: Yayasan Penerbit UI, 1975.

Suyūṭī (al). Al-Radd 'alā Man Akblada ilā al-'Ard wa Jabila anna alIjtihäd fi Kull 'A sr Fard. Aljazair: Maṭba'at al-Jazāir, $1325 \mathrm{H}$.

Syarifuddin, Amir. Usul Fikih I. Jakarta: Logos Wacana Ilmu, 1997. Ṭantāwī, Muhammad Sayyid. Al-Ijtihād fì al-Aḥkām al-Sharìyah. Cairo: al-Azhar al-Sharīf, 2007.

. Mu'ámalāt al-Bunūk wa Aḅkāmubā al-Shar'ìyah. Cairo: Hay'at alMișrīyah li al-Kitāb, 1998.

Yahya, Mukhtar and Fatchurrahman. Dasar-dasar Pembinaan Hukum Islam. Bandung: Al Ma’arif, 1997.

Zahrah, Muhammad Abū. Ușūl al-Fiqh. Beirut: Dār al-Fikr, n.d. Zaydān, 'Abd al-Karīm. al-Wajì fì Ușūl al-Fiqh, Vol. 6. Beirut: Mu'assasat al-Risālah, 1994. 
Zuhaylī (a), Wahbah. Usūul al-Figh al-Islāmì. Beirut: Dār al-Fikr alMu'āṣir, 2001. 